\title{
DISORDER PRAGMATIK ANAK TUNA RUNGU DALAM INTERAKSI PEMBELAJARAN DI KELAS
}

\author{
Abdul Syukur Ibrahim dan Suko Winarsih \\ Fakultas Sastra Universitas Negeri Malang \\ e-mail: asibra@yahoo.com
}

\begin{abstract}
Abstrak
Penelitian ini bertujuan mengungkapkan disorder pragmatik anak tuna rungu dalam interaksi pembelajaran di kelas, meliputi (1) wujud tutur anak tuna rungu, (2) kendala tutur anak tuna rungu, dan (3) intervensi guru terhadap disorder pragmatik anak tuna rungu. Penelitian ini menggunakan rancangan deskriptif kualitatif. Data penelitian ini berupa data deskriptif dan data reflektif. Hasil penelitian sebagai berikut. Pertama, wujud tutur anak tuna rungu meliputi tindak ilokusi, fungsi tutur, dan strategi bertutur. Kedua, kendala tutur anak tuna rungu terutama terjadi pada bentuk tutur sehingga ujaran mereka sering terdengar tidak jelas. Ketiga, guru melakukan intervensi terhadap tindak tutur, fungsi tutur, dan strategi bertutur anak tuna rungu dalam interaksi pembelajaran di kelas.
\end{abstract}

Kata kunci: disorder pragmatik, bentuk tutur, fungsi tutur, kendala tutur

\section{PRAGMATIC DISORDERS AMONG DEAF CHILDREN IN CLASSROOM LEARNING INTERACTIONS}

\begin{abstract}
This study aims to reveal pragmatic disorders among deaf children in classroom learning interactions in terms of: (1) their speech forms, (2) their speech constraints, and (3) teachers' intervention. It employed a qualitative descriptive design. The data consisted of descriptive and reflective data. The findings are as follows. First, the deaf children's speech forms include illocutionary acts, speech functions, and speech strategies. Second, their speech constraints are especially in the speech forms that make their utterances often unclearly audible. Third, the teachers make intervention in speech acts, speech functions, and speech strategies among deaf children in the learning classroom interactions.
\end{abstract}

Keywords: pragmatic disorders, speech forms, speech functions, speech constraints

\section{PENDAHULUAN}

Penelitian pragmatik yang berkembang saat ini mengarah ke bidang kajian neuro-pragmatik yang dikenal dengan istilah pragmatik klinis (clinical pragmatics). Cummings (2009:6) mendefinisikan pragmatik klinis sebagai studi tentang cara penggunaan bahasa seseorang dalam berkomunikasi yang mengalami kekacauan pragmatik. Kekacauan pragmatik berhubungan dengan faktor kognitif dan linguistik. Salah satu aspek klinis yang merefleksikan ketertarikan para ahli klinis di bidang pragmatik adalah pengklasifikasian perkembangan disorder bahasa. Ide-ide Austin (1962) dan Grice (1981) tentang penggunaan bahasa secara kontekstual mengalami perkembangan ke arah pragmatik klinis. Para ahli klinis melakukan penelitian secara berkesinambungan, dengan melakukan penilaian (assessment) dan pelatihan (treatment) kepada anak-anak yang mengalami hambatan berbahasa. Contohnya, performansi bahasa anak normal menunjukkan bahwa pola berkomunikasi mereka seperti pola 
berkomunikasi anak autis (Cummings, 2009:11).

Pragmatik klinis merujuk pada deskripsi dan klasifikasi kerusakan kompetensi pragmatik, dan memberikan penjelasan teoretis mengenai variasi pragmatik, linguistik, kognitif, dan neurologi, serta cara melakukan assessment dan treatment terhadap mereka. Kemampuan dan ketidakmampuan pragmatik merupakan dampak dari interaksi yang kompleks antara semiotik, kognitif, dan sistem sensorimotor. Pragmatik klinis muncul karena perkembangan bidang psikologi, neurologi dan pragmatik.

Daya tarik kajian pragmatik klinis mirip dengan kajian pragmatik pada umumnya. Hasil pemikiran para filosof, H.P Grice, J.L Austin, dan J. Searle (1979) merupakan reaksi kritis terhadap pandangan umum bahasa yang dikemukakan oleh sebagian besar filosof pada awal abad ke-20. Buktinya, Austin menolak pendapat bahwa kalimat deklaratif selalu digunakan untuk mendeskripsikan suatu peristiwa. Ia mengatakan hal ini sebagai kesalahan deskriptif (descriptive fallacy). Kalimat deklaratif, sebagaimana diargumentasikan oleh Austin, ternyata tidak saja mendeskripsikan sesuatu tetapi juga menyatakan tindakan performatif. Austin (1962:81) mengatakan bahwa ujaran performatif (1) tidak mendeskripsikan atau melaporkan sesuatu, tidak juga memutuskan sesuatu itu benar atau salah, dan (2) pengutaraan kalimat merupakan bagian dari suatu tindakan, dan bukan sekadar mengatakan sesuatu.

Pandangan bahwa bahasa dapat digunakan untuk melakukan sesuatu melahirkan cabang linguistik, yaitu pragmatik. Perhatian utamanya adalah penggunaan bahasa dalam situasi komunikasi seharihari, misalnya penyampaian permintaan, pengekspresian janji, dan pendeskripsian peristiwa atau maksud tertentu. Grice (dalam Cole \& Cole, 1981:102) melakukan analisis secara revolusioner terhadap ujaran-ujaran yang mempunyai implikasi tertentu. Ia menyatakan terdapat perbedaan antara ujaran dan hal-hal yang secara konvensional mengimplikasikannya. Suatu contoh, ujaran "Beberapa siswa lulus ujian" mengimplikasikan bahwa tidak semua siswa lulus ujian. Hal ini merupakan kekhususan, meskipun terdapat kekonsistenan logika, antara ujaran "Beberapa siswa lulus ujian" dan "Semua siswa lulus ujian". Sebagaimana implikatur konvensional, Grice memperkenalkan kategori implikatur yang memengaruhi perkembangan pragmatik. Pengetahuan mengenai implikatur konvensional ini merupakan salah satu fenomena pragmatik yang akan diinvestigasi secara ekstensif dalam literatur klinis.

Para praktisi dan peneliti klinis mengatakan bahwa assessment dan treatment disorder bahasa pada anak-anak dan orang dewasa memerlukan perubahan teori pragmatik. Jauh sebelumnya, para filosof bahasa, seperti Austin dan Grice telah menunjukkan ketidakkuatan kerangka semantik dan logika. Semantik dan logika ternyata tidak mampu menganalisis bagaimana penutur menggunakan bahasa dalam suatu konteks tertentu. Penggunaan bahasa dalam komunikasi nyata sehari-hari sarat dengan konteks, situasi dan kondisi psikologis dan sosiologis. Ujaran dapat dipahami maksudnya apabila berada dalam konteks. Hal ini membawa implikasi terhadap hadirnya ujaran tersebut, yang disebut implikatur.

Studi pragmatik klinis menekankan pada teknik assessment bahasa pada penyandang disorder bahasa, khususnya klien dewasa. Para ahli klinis tertarik menguji bagaimana seorang klien menggunakan keterampilan berbahasa dalam berkomunikasi. Hasil assessment menunjukkan bahwa para ahli klinis meng-asses berbagai macam faktor keterampilan berbahasa. Faktor konteks, misalnya tidak dapat di-asses oleh sederetan perangkat assessment yang diusulkan oleh para ahli, seperti Boston Diagnostic Aphasia Examinition dan Western Aphasia Battery 
(Carrow-Woolfolk dan Lynch, 1982:197). Faktor sosial, suatu misal kesantunan berbahasa lebih sedikit meng-asses bahasa formal, karena hal tersebut lebih banyak berhubungan dengan pola-pola variasi penggunaan bahasa antara seorang klien dan mitra tuturnya.

Disorder pragmatik berhubungan dengan defisit bahasa, yaitu kurangnya penguasaan sistem bahasa dan penggunaannya. Anak-anak dengan kekacauan bahasa terbiasa dengan konteks komunikasi yang menuntut penggunaan tindak tutur tidak langsung. Penutur pertama gagal menggunakan tindak permintaan tidak langsung dalam situasi tertentu, karena ia harus mempertimbangkan aspek kesantunan dan latar belakang sosial tertentu dalam percakapan. Sebaliknya, penutur kedua tidak mengalami hambatan dalam mengekspresikan bahasa, khususnya lingkup sintaksis dan semantik, tetapi ia tidak dapat merumuskan tindak tutur tertentu. Dengan demikian, disorder pragmatik hanya terjadi pada penutur dengan keterampilan bahasa yang utuh, yaitu penutur kedua.

Para ahli patologi bahasa, pendidik atau guru, ahli kognitif dan neurologi, linguis, psikolog dan psikiatris adalah orang-orang yang mempunyai ketertarikan dalam melihat bagaimana pragmatik bahasa dipengaruhi oleh kerusakan otak atau masalah lain yang memengaruhi perkembangan masa remaja atau dewasa. Pembahasan pragmatik klinis memerlukan pengetahuan tentang teknik neuroanatomi dan neuroimaging, kognisi, psikologi, akuisisi dan proses bahasa, kerusakan otak, dan hal-hal lain yang berkaitan. Pragmatik klinis merupakan fenomena kebahasaan pada orang dewasa dan anak-anak yang mengalami hambatan klinis, misalnya para penderita keterbelakangan mental/mentally retarded (seperti Down's Syndrome/William's Syndrome, Asperger's Syndrome), Parkinsons, Alzaimer, Scizofrenia dan hearing loss (tuna rungu).
Pendek kata, ketika merencanakan intervensi pragmatik, ahli klinis dan guru harus mempertimbangkan faktor-faktor yang memengaruhi keterampilan pragmatik anak. Selama interaksi berlangsung, keterampilan yang berhubungan dengan pragmatik, misalnya pemindahgiliran pembicaraan dan penggunaan tindak tutur, diusahakan berada dalam konteks alamiah. Owens (1991:215) mengatakan bahwa kegiatan terapi memperbaiki fungsi hemisfer kanan, yaitu bagin otak yang mengurusi masalah pragmatik dalam komunikasi verbal dengan menggunakan fitur-fitur paralinguistik, seperti intonasi, gestur, dan ekspresi wajah.

Sehubungan dengan penemuan teoretis dan praktis sebagaimana telah dikemukakan, penelitian ini dilakukan pada anak tuna rungu. Secara fisik, anak tuna rungu tidak berbeda dengan anak normal dengar pada umumnya. Orang baru mengetahui bahwa anak tersebut menyandang ketunarunguan pada saat ia berbicara. Dampak ketunarunguan adalah ketidakmampuan anak berkomunikasi verbal.

Penyebab ketunarunguan sebagian besar adalah faktor bawaan, yang terjadi karena keturunan atau adanya toksin sejak masa prakelahiran ataupun sebab-sebab lain. Sedangkan ketunarunguan yang terjadi karena sesuatu hal disebabkan oleh berbagai macam toksin atau infeksi telinga spesifik, misalnya, media otitis (Carrow-Woolfolk dan Lynch, 1982:371).

Penyebab utama ketunarunguan bawaan yang tidak berasal dari keturunan adalah toksin yang menyerang ibu saat bulan-bulan awal kehamilan. Toksin yang umum menyerang adalah rubella dan cytomegalovirus (Northern dan Downs, 1978:86), dan penyebab lain, seperti syphilis, toxemia dan diabetes. Evaluasi klinis pendengaran seharusnya dilakukan sedini mungkin sejak awal kelahiran anak untuk mengantisipasi risiko tinggi terhadap gangguan pendengaran. Faktorfaktor risiko tinggi tersebut adalah (1)

Disorder Pragmatik Anak Tuna Rungu dalam Interaksi Pembelajaran di Kelas 
riwayat keturunan ketunarunguan di dalam keluarga, (2) virus rubella yang menyerang ibu hamil, (3) infeksi yang fatal, (4) kerusakan atau kecacatan telinga, hidung dan tenggorokan, (5) kelahiran bayi dengan berat badan kurang dari 1500 gram, (6) serum bilirubin lebih dari 20 miligram per 100 milimeter, dan (7) potensi cytomegalovirus bawaan (Lloyd dan Dahle, 1976:12-22).

Anak-anak yang lahir dengan pendengaran normal mungkin kehilangan pendengarannya selama masa kanak-anak karena berbagai penyakit, seperti campak atau cacar air, penyakit gondong, meningitis (radang selaput otak atau tulang belakang), enchepalitis (radang otak) dan infeksi lain akibat penggunaan obat-obat ototoksik yang mengakibatkan kehilangan pendengaran secara serius. Selain itu, ketunarunguan juga disebabkan oleh infeksi telinga (akut, kronis atau media otitis serius). Batasan ketunarunguan tidak terbatas pada kehilangan pendengaran yang sangat berat, melainkan juga mencakup seluruh tingkat kehilangan pendengaran dari tingkat ringan, sedang, berat sampai sangat berat.

Menurut Moores (1978:173-194) definisi ketunarunguan ada dua kelompok. Pertama, seseorang dikatakan tuli apabila kehilangan kemampuan mendengar pada tingkat $70 \mathrm{~dB}$ Iso atau lebih, sehingga ia tidak dapat mengerti pembicaraan orang lain melalui pendengarannya baik dengan ataupun tanpa alat bantu mendengar. Kedua, seseorang dikatakan kurang dengar bila kehilangan pendengaran pada $35 \mathrm{~dB}$ Iso sehingga ia mengalami kesulitan memahami pembicaraan orang lain melalui pendengarannya baik tanpa maupun dengan alat bantu mendengar.

Dari berbagai batasan yang dikemukakan oleh para pakar ketunarunguan tersebut dapat disimpulkan bahwa ketunarunguan adalah suatu keadaan atau derajat kehilangan pendengaran yang meliputi seluruh gradasi dari ringan, sedang hingga sangat berat. Dalam hal ini derajat ketunarunguan dikelompokkan ke dalam dua golongan, yaitu tuli (hearing loss) dan kurang dengar (hearing impaired). Seseorang dikatakan tuli apabila berdasarkan pengukuran audiometrik daya tangkap pendengarannya lebih dari $90 \mathrm{~dB}$. Seseorang dikatakan kurang dengar apabila berdasarkan pengukuran audiometrik, yaitu suatu alat yang digunakan untuk mengukur kemampuan mendengarkan bunyi, daya tangkap pendengarannya antara 70 hingga $90 \mathrm{~dB}$, yang walaupun telah diberikan alat bantu mendengar tetap memerlukan pelayanan khsusus.

Anak-anak yang tingkat ketunarunguannya tinggi adalah mereka dengan kondisi pendengaran sangat minim, yaitu mereka yang mengalami kecacatan telinga sampai usia 2 tahun. Penelitian Holm dan Kunz (1969:833-839) menunjukkan bahwa anak-anak yang pendengarannya mendekati normal sampai dengan kehilangan pendengaran hingga $25 \mathrm{~dB}$ keterampilan berbahasanya rendah bila dibandingkan dengan kelompok kontrol. Howie, Ploussard, dan Sloyer (1976:18) menemukan bahwa anak-anak penderita otitis media yang direkam sebanyak tiga episode pada tahun pertama menunjukkan skor rata-rata lebih rendah secara signifikan pada WISC-R daripada kelompok kontrol.

Recek audiometrik secara rutin sangatlah penting untuk anak tuna rungu, baik derajat yang ringan maupun yang berat. Northern dan Downs (1978:274) melaporkan bahwa terdapat derajat kerusakan yang agak tinggi pada anakanak tuna rungu. Jenis lain dari ketunarunguan, seperti yang berhubungan dengan infeksi cytomegavirus bawaan memerlukan pemantauan yang hati-hati dan khusus untuk memastikan bahwa derajat ketunarunguannya tidak semakin bertambah.

Dalam interaksi pembelajaran di kelas, hal yang perlu mendapatkan perhatian adalah bagaimana siswa tuna rungu melakukan komunikasi verbal, baik de- 
ngan guru maupun temannya. Berdasarkan wujudnya, disorder pragmatik terdiri atas tiga unsur pokok, yaitu tindak tutur, fungsi tutur, dan strategi bertutur. Wujud tutur merupakan jenis atau ragam tuturan yang digunakan oleh seorang penutur dalam menyampaikan pesan kepada mitra tutur. Jadi, wujud tutur berkaitan erat dengan tindak tutur, fungsi tutur, dan strategi bertutur (Searle, 1979).

Tindak tutur secara pragmatis selalu berhubungan dengan makna secara kotekstual, yaitu peristiwa-peristiwa yang melatarbelakangi hadirnya tuturan, seperti peristiwa interaksi belajar-mengajar yang terjadi di SMALB-B YPTB Malang.

Berdasarkan hal-hal yang telah diuraikan, penelitian ini difokuskan pada disorder pragmatik anak tuna rungu dalam interaksi pembelajaran di kelas, yang meliputi (1) wujud tutur anak tuna rungu, (2) kendala tutur anak tuna rungu, dan (3) intervensi guru terhadap disorder pragmatik anak tuna rungu dalam interaksi pembelajaran di kelas.

\section{METODE}

Penelitian ini menggunakan rancangan deskriptif kualitatif. Data penelitian ini berupa data deskriptif dan data reflektif. Pertama, data deskriptif ditampilkan dalam bentuk (a) transkripsi tuturan yang diproduksi oleh anak tuna rungu dan guru dalam proses interaksi pembelajaran di kelas, yang ditransfer berdasarkan rekaman wacana utuh dari video recorder, dan (b) penggalan tuturan, yang diujarkan oleh siswa tuna rungu dan para guru. Kedua, data reflektif berupa catatan lapangan/anekdot berdasarkan observasi langsung.

\section{HASIL PENELITIAN DAN PEMBA- HASAN \\ Wujud Tutur Anak Tuna Rungu}

Klasifikasi wujud tutur berdasarkan rumusan masalah penelitian ini terdiri atas (1) tindak tutur, (2) fungsi tutur, dan (3) strategi bertutur anak tuna rungu dalam interaksi pembelajaran di kelas. Pertama, tindak tutur anak tuna rungu secara pragmatis meliputi tindak asertif, tindak direktif, tindak komisif, dan tindak ekspresif. Tindak tutur secara pragmatis berupa tindak tutur ilokusi berdasarkan klasifikasi Searle (1979: 11), yang meliputi (a) tindak asertif, (b) tindak direktif, (c) tindak komisif, (d) tindak ekspresif, dan (e) tindak deklaratif. Berdasarkan hasil analisis data tidak ditemukan tindak ilokusi deklaratif. Hal ini dapat dipahami karena tindak deklaratif hanya dituturkan oleh orang-orang tertentu yang mempunyai kewenangan (authority), misalnya penghulu yang menikahkan sepasang pengantin secara Islam, kepala negara yang meresmikan sebuah gedung pemerintahan.

Kedua, fungsi tutur diklasifikasikan atas (1) fungsi komunikatif dan (2) fungsi nonkomunikatif (Carrow-Woolfolk dan Lynch, 1982:180-187). Hasil analisis data menunjukkan bahwa fungsi komunikatif yang digunakan oleh anak tuna rungu ditandai oleh enam indikator, yaitu menyapa, mengatur, bertukar informasi, mengekspresikan perasaan, menggunakan bahasa secara imajinatif, dan menggunakan metalinguistik. Dan fungsi nonkomunikatif tercermin ke dalam tiga indikator, yaitu formasi konsep, arahan-diri, dan mejik. Dengan demikian dapat dikatakan bahwa fungsi tutur yang digunakan oleh anak tuna rungu sama dengan yang digunakan oleh anak normal dengar.

\section{Kendala Tutur Anak Tuna Rungu}

Anak tuna rungu mempunyai kendala berkomunikasi secara verbal. Kendala tutur tersebut dapat diklasifikasikan dari segi bentuk tutur, fungsi tutur, dan strategi bertutur. Pertama, kendala dari segi bentuk tutur, meliputi kesulitan menangkap bunyi bahasa, kesulitan mengucapkan bunyi bahasa, kesulitan membedakan hal yang didengar, kesulitan mengingat, kesulitan memahami konteks wacana 
dan kesulitan mengucapkan kata atau kalimat dengan artikulasi yang jelas. Kedelapan kendala tersebut merupakan ciri khas yang dialami anak tuna rungu (Suherman, 2005:7). Hasil analisis data penelitian menunjukkan bahwa anak tuna rungu mengalami keenam kendala dari segi bentuk tutur tersebut.

Kedua, kendala fungsi tutur meliputi kendala fungsi komunikatif dan nonkomunikatif. Kendala fungsi komunikatif mempunyai enam hal, yaitu menyapa, mengatur, bertukar informasi, mengekspresikan perasaan, menggnakan bahasa secara imajinatif, dan menggunakan metalinguistik (Carrow-Woolfolk dan Lynch, 1982:183-185). Dari analisis data ditemukan bahwa dari keenam kendala fungsi komunikatif tersebut, kendala yang dialami oleh anak tuna rungu meliputi dua hal, yaitu kendala betukar informasi, dan menggunakan metalinguistik dengan frekuensi sedikit atau kadang-kadang terjadi. Kendala fungsi nonkomunikatif meliputi kendala formasi konsep, kendala arahan diri, dan kendala mejik (CarrowWoolfolk dan Lynch, 1982:185-188). Berdasarkan temuan penelitian anak tuna rungu mengalami kendala ketiga fungsi nonkomunikatif tersebut, meskipun frekuensinya sedikit.

Ketiga, strategi bertutur terdiri atas tiga klasifikasi, yaitu (1) berdasarkan kelangsungan cara pengungkapannya, (2) berdasarkan keliteralan pengujarannya, dan (3) interseksi atau kombinasi dari keduanya (Wijana, 1996:30). Strategi bertutur berdasarkan kelangsungan pengungkapannya adalah strategi langsung dan strategi tidak langsung. Strategi bertutur langsung adalah cara yang digunakan oleh penutur dalam menyampaikan pesan dengan menggunakan tindak tutur langsung (direct speech act). Yang termasuk strategi bertutur langsung adalah kalimat berita (deklaratif), kalimat tanya (interogatif), dan kalimat perintah (imperatif). Strategi bertutur tidak langsung adalah cara bertutur seseorang yang tuturannya diutarakan secara tidak langsung dan biasanya tidak dapat dijawab secara langsung, tetapi harus dipahami terlebih dulu maksud yang terimplikasi di dalamnya (Wijana, 1996:30-31). Dari hasil analisis data ditemukan bahwa anak tuna rungu menggunakan strategi bertutur langsung, baik literal maupun tidak literal. Hal ini dapat dimaklumi karena daya pikir mereka sangat terbatas akibat terhambatnya kemampuan mendengarkan.

\section{Intervensi Guru terhadap Ekspresi Tutur Anak Tuna Rungu}

Intervensi guru terhadap ekspresi tutur anak tuna rungu di dalam interaksi pembelajaran di kelas meliputi tiga hal, yaitu (1) intervensi terhadap tindak tutur, (2) intervensi terhadap fungsi tutur, dan (3) intervensi terhadap strategi bertutur.

Pertama, intervensi terhadap tindak tutur meliputi (1) intervensi tindak ilokusi (Owens, 1991: 69-73), (2) intervensi kemampuan percakapan (Owens, 1991:221227), (3) intervensi pemahaman (Cole \& Cole, 1981:39-45), dan (4) intervensi narasi (Moeller \& McConkey, 1984:11-25). Berdasarkan hasil analisis data, ditemukan bahwa intervensi guru dari segi tindak tutur ilokui, meliputi indikator meminta perhatian, meminta tindakan, meminta klarifikasi, meminta informasi, meminta objek, merespon, dan meminta pendapat, sebagaimana dikemukakan oleh Owens (1991: 69-73). Intervensi kemampuan percakapan mempunyai lima kategori, yaitu presuposisi, menyarankan berdiskusi, meminta penjelasan detail, meminta pendapat, dan pemerbaikan percakapan (Owens, 1991:221-227).

Hasil analisis data pada carta data terpilih menunjukkan bahwa guru melakukan kelima kategori intervensi tersebut. Intervensi pemahaman dilakukan oleh guru melalui lima cara sebagaimana dikemukakan oleh Cole \& Cole (1981:3945), yaitu memberikan pemahaman referensial, memanipulasi isi semantik, performansi topik, pemeliharaan topik, 
dan mengulang. Intervensi narasi oleh guru dilakukan melalui tiga cara (Moeller \& McConkey, 1984:11-25), yaitu melibatkan siswa dalam kegiatan terorganisasi, membantu siswa mentransfer kegiatan dalam bentuk organisasi linguistik, dan membacakan cerita. Hasil analisis data menunjukkan bahwa intervensi narasi yang diakukan oleh guru mencakup ketiga hal tersebut.

Kedua, intervensi guru terhadap fungsi tutur mempunyai dua cara, yaitu (1) intervensi secara direktif, dan (2) intervensi secara fasilitatif (Mirenda \& Donellan, 1986:126-141). Intervensi secara direktif adalah bentuk campur tangan guru terhadap ekspresi tutur anak tuna rungu dengan cara berinisiasi separuh dari percakapan, menggunakan pertanyaan langsung, menggunakan imitasi atau ekspansi untuk mengatur topik, dan menggunakan kalimat imperatif. Hasil penelitian menunjukkan bahwa guru melakukan intervensi secara direktif melalui keempat cara tersebut.

Selanjutnya, intervensi dari segi fungsi tutur yang dilakukan oleh guru selain secara direktif adalah intervensi secara fasilitatif. Dalam hal ini guru bertindak sebagai fasilitator bagi siswa untuk dapat melakukan komunikasi verbal. Sementara itu, intervensi secara fasilitatif, meliput berinisiasi kurang dari separuh percakapan, menggunakan pertanyaan tidak langsung, menggunakan pernyataan untuk mengatur topik, dan guru memberikan pemindahgiliran. Hasil analisis data menunjukkan bahwa intervensi guru secara fasilitatif meliputi keempat cara tersebut.

Ketiga, intervensi guru terhadap strategi bertutur mempunyai dua bagian: (1) manipulasi konteks dan (2) intervensi presimbolik dan simbolik minimal (Owens, 1991:283). Manipulasi konteks yang dilakukan oleh guru adalah manipulasi konteks nonlinguistik dan linguistik sebagaimana dikemukakan oleh Norris \& Hoffman (1990:72-84). Idealnya, konteks non- linguistik mendukung pemerolehan bahasa target. Guru dapat membantu anak memodifikasi bahasa target ke dalam tindak yang benar pada situasi tertentu.

Secara teoretis, anak yang menghasilkan respon yang bermakna dalam konteks tertentu akan tertarik terhadap respon tersebut dan termotivasi untuk mengubahnya sesuai dengan keinginan. Respon ini harus dapat menggeneralisasikan penggunaan bahasa sehari-hari. Penggunaan bahasa untuk komunikasi sehari-hari dapat dilatihkan oleh guru dalam konteks peristiwa dan percakapan sehari-hari.

Berdasarkan temuan penelitian melalui analisis carta data terpilih, satu-satunya data yang ditemukan dari hasil analisis mengenai manipulasi konteks nonlinguistik adalah ujaran, "Bu Ludvi tidak ada." (LV57). Bu Ludvi keluar ruang kelas dengan harapan Dinia mau bercerita tentang topik pencemaran lingkungan kepada teman-temannya di depan kelas. Bu Ludvi merasa bahwa Dinia malu-malu untuk bercerita, sehingga Bu Ludvi punya inisiatif keluar ruang kelas. Konteks linguistik untuk anak tuna rungu meliputi isyarat linguistik langsung (direct linguistic cues), dan isyarat linguistik tidak langsung (indirect linguistic cues). Isyarat linguistik langsung digunakan untuk memeroleh kategori kata dalam ranah sintaksis, misalnya: kata kerja, subjek kata benda, objek kata benda, frase adverbial, dan katakata khusus, dll. Isyarat linguistik tidak langsung (indirect linguistic cues) adalah percakapan dalam situasi yang alami. Contoh manipulasi konteks linguistik adalah ujaran Bu Rini berikut ini.

"Coba lagi ya! Masalah atau Bukan. Di ruang internet... halaman depan selalu kotor sehingga anak-anak SMALB tidak dapat belajar dengan baik. Masalah atau bukan?" (RN347).

Selanjutnya, intervensi presimboik adalah campur tangan guru dalam mengembangkan ketrampilan tertentu. Sedangkan intervensi simbolik minimal ada- 
lah campur tangan guru dalam mengembangkan ketrampilan sehubungan dengan fungsi ilokusi (Owens, 1991:319). Bentuk intervensinya adalah mengoptimalkan sistem komunikasi, dan peran komunikasi argumentatif. Hasil penelitian menunjukkan bahwa guru melakukan kedua bentuk intervensi tertsebut.

\section{SIMPULAN DAN SARAN}

Kajian ini dimaksudkan mengungkapkan tiga hal pokok yang relevan dengan ekspresi tutur anak tuna rungu dalam interaksi pembelajaran di kelas. Tiga hal pokok itu adalah wujud tutur, kendala tutur, dan intervensi guru terhadap ekspresi tutur anak tuna rungu dalam interaksi pembelajaran di kelas.

Wujud tutur anak tuna rungu, meliputi tindak ilokusi, fungsi tutur, dan strategi bertutur. Pertama, tindak ilokusi yang diproduksi oleh anak tuna rungu dapat dikatakan sama dengan anak normal dengar. Tindak ilokusi tersebut adalah (1) asertif, (2) direktif, (3) komisif, dan (4) ekspresif. Kedua, hasil temuan penelitian mengenai fungsi tutur menunjukkan bahwa secara umum anak tuna rungu memanfaatkan fungsi tutur komunikatif dan nonkomunikatif. Ketiga, hasil penelitian penggunaan strategi bertutur menunjukkan bahwa anak tuna rungu menyampaikan secara langsung.

Kendala tutur anak tuna rungu terutama terjadi pada bentuk tutur. Ujaran mereka sering terdengar tidak jelas. Hal ini terjadi karena mereka mengalami kesulitan menangkap bunyi bahasa, mengucapkan bunyi bahasa, membedakan hal yang didengar, mengingat, memahami konteks wacana. Implikasinya, mereka mengalami kesulitan mengucapkan kata atau kalimat dengan artikulasi yang jelas. Suatu fenomena unik ditemukan bahwa semua tuturan anak tuna rungu disampaikan dengan menggunakan strategi langsung.
Guru melakukan intervensi terhadap tindak tutur, fungsi tutur, dan strategi bertutur anak tuna rungu dalam interaksi pembelajaran di kelas.

Berdasarkan hasil penelititian dikemukakan saran-saran berikut ini. Para dosen atau tenaga pengajar pada program studi Bahasa dan Sastra Indonesia (Fakultas Sastra) dan program studi Pendidikan Bahasa dan Sastra Indonesia disarankan untuk mengembangkan silabus dan materi perkuliahan semantik, pragmatik, dan psikolinguistik dengan mengembangkannya pada disorder bahasa anak tuna rungu.

Para guru SLB tuna rungu disarankan dapat menangani siswa dalam hal kemampuan berbicara, menyimak pembicaraan, ekspresi menulis, memahami bacaan, kelancaran membaca, berhitung, dan berpikir matematis (memecahkan masalah). Selain itu, para guru tersebut disarankan dapat memberikan treatmen dan terapi terhadap masalah kesalahan ejaan, kesalahan membedakan hal yang didengar, kesulitan mengenal huruf, kesulitan menangkap dan mengucapkan bunyi-bunyi bahasa tertentu, kesalahan membilang dan mengenal kembali angka, kesulitan mengingat, dan kesalahan ucapan unsur kata.

Para pengembang kurikulum untuk sekolah berkebutuhan khusus atau berkesulitan belajar, terutama SLB-B (tuna rungu) disarankan dapat mengembangkan kurikulum dan silabus yang mempunyai karakter khusus ketunarunguan.

Kepada para peneliti lanjut diharapkan melakukan penelitian-penelitian lain yang sejenis. Misalnya, penelitian yang berhubungan dengan kompetensi pragmatik anak dengan disorder bahasa (language disorder), seperti anak autisme, keterbelakangan mental (mental retardation), Down's Syndrome, William's Syndrome, Asperger's Syndrome, dan lain-lain. 


\section{UCAPAN TERIMA KASIH}

Ucapan terima kasih disampaikan kepada siswa dan Guru-guru di SMALB-B YPTB Malang yang telah membantu kegiatan pengumpulan data. Terima kasih disampaikan kepada teman sejawat yang telah banyak memberikan masukan dan koreksi yang sangat bermanfaat demi perbaikan proses dan hasil penelitian ini. Mudah-mudahan temuan penelitian ini bermanfaat bagi para pemerhati pembelajaran bahasa, hususnya bagi anak-anak berkebutuhan khusus.

\section{DAFTAR RUJUKAN}

Austin, JL. 1962. How to Do Thing with Words. Oxford: Clarendon Press

Carrow-Woolfolk, E. \& Lynch, JI. 1982. Integrative Approach to Language in Children. New York: Grune \& Stratton, In

Cole, M., \& Cole, J. 1981. Effective Intrvention with the Language-Impaired Child. Rockville, MD: Aspen

Cummings, L. 2009. Clinical Pragmatics. Cambridge: Cambridge University Press

Grice, HP.1981. "Presupposition and Conversational Implicature" dalam Cole P (Ed). Radical Pragmatics. New York: Academic Press

Holm, VA., \& Kunz, LH. 1969. Effect of Chronic Otitis Media on Language and Speech Development. Pediatrics 43

Howie, VM., Ploussard, JH., \& Sloyer, JL. 1976. Natural History of Otitis Media. Ann Otol Rhinol Laryngol (suppl) 25, 85
Lloyd, L., \& Dahle, A. 1976. Detection and Diagnosis of a Hearing Impairment in the Child. Volta Review 78

Mirenda, P., \& Donnellan, A. 1986. Effects of Adult Interaction Style on Conversational Behavior in Students with Severe Communication Problems. Language, Speech, and Hearing Services in Schools 21

Moeller, M., \& McConkey, A. 1984. Language Intervenion with Preschool Deaf Children: A Cognitive/Linguistic Approach. Dalam W. Perkins (Ed). Current Therapy of Communication Disorders; Hearing Disorders. New York: Thieme-Stratton

Moores, DF. 1978. Current Research and Theory with the Deaf: Educational Implications. Dalam Liben, LS (Ed). Deaf Children: Developmental Perspectives. New York: Academic Press

Northern, JL., \& Downs, MP. 1978. Hearing in Children (ed 2). Baltimore: Wiliams \& Wilkins

Owens, RE. 1991. Language Disorder. A Functional Approach to Assessment and Intervention. New York: Macmillan Publishing Company

Searle, JR. 1979. Speech Acts: an Essay in the Philosophy of Langauage. Cambridge: Cambridge University Press

Suherman, Y. 2005. Adaptasi Pembelajaran Siswa Berkesulitan Belajar Melalui Pendekatan Multidisipliner. Bandung: Rizqi Press

Wijana, IPD. 1996. Dasar-dasar Pragmatik. Yogyakarta: Andi Offset 